\title{
Effect of Integrated Pest Management Strategies on Chlorothalonil, Metalaxyl, and Thiophanate-methyl Runoff at a Container Nursery
}

\author{
Jeanne Briggs, Ted Whitwell, R. Thomas Fernandez, ${ }^{1}$ and Melissa B. Riley ${ }^{2}$ \\ Department of Horticulture, Clemson University, Clemson, SC 29634
}

\begin{abstract}
ADDITIONAL INDEX WORDS. container plant production, fungicide, runoff water
Abstract. Field research was conducted at a container nursery to investigate fungicide movement in runoff water. Fungicides were applied as either a preventative treatment to all container plants, or as a component of an integrated pest management (IPM) program in which fungicides were only applied to plants showing signs of pathogen infestation. Thiophanate-methyl and chlorothalonil were applied in July and August 1998, and metalaxyl was applied in September 1998. Runoff water was sampled on the day after application (first irrigation after pesticide application) through three pulse irrigation cycles. Total amounts of thiophanate-methyl and chlorothalonil in runoff water were $7 \%$ and $4 \%$, respectively, of applied amount in July. In August, $2 \%$ and $4 \%$ of thiophanate-methyl and chlorothalonil were found from the preventative treatment. Of the applied metalaxyl, $25 \%$ was detected in runoff water for the first irrigation event after application from the preventative treatment. Metalaxyl is a highly water soluble pesticide and nontarget losses from the granular application contributed to the large amounts detected. Total amounts of thiophanate-methyl, chlorothalonil and metalaxyl detected in runoff from the IPM treatment were $25 \%$ of amounts from the preventative treatment. No treatment differences were found in container plant salability or in the number of culls at the end of the study.
\end{abstract}

Container-grown plants are managed to produce a quality product in a short time period. Management practices include frequent fertilization and daily irrigation so that neither nutrients nor water is deficient during the container plant growing season. Conditions that are optimal for plant growth are equally optimal for proliferation of many plant pathogens, and fungicides are routinely used in container nurseries to prevent and manage pathogen infestations. Fungicide residues were previously detected in runoff water from a container nursery (Briggs et al., 1998a). Concern for the possibility of contamination of aquatic ecosystems warrants investigation of management practices that will reduce pesticide levels in runoff water.

A basic tenet of integrated pest management (IPM) is the reduction of quantities of applied pesticides through a holistic management strategy. Defined as "the judicious use and integration of various pest control tactics, in the context of the associated environment of the pests, in ways that complement and facilitate biological control and other ecological processes that reduce pest impact, to meet economic and environmental goals" (Holtzer et al., 1996), IPM was developed as a management strategy to reduce pesticide inputs in response to problems that occurred after the release of synthetic organic insecticides following World War II (Cardina et al., 1999; Holtzer et al., 1996). Pests are recognized as a component of an agroecosystem and any management action is viewed as having impacts on many aspects of the ecosystem. At present, IPM is used as a management strategy for control of insects, pathogens, and weeds (Cardina et al., 1999; Cook, 1994).

Widely used as a management practice in fruit and vegetable production, IPM is most applicable to a single-pest, single-plant species approach. As a container plant nursery may grow up to

Received for publication 20 Nov. 2001. Accepted for publication 23 July 2002. Clemson University technical contribution no. 4771. This paper is a portion of a dissertation submitted by Jeanne Briggs. Mention of a trademark, proprietary product, or vendor does not constitute a guarantee or warranty of the product by the USDA and does not imply its approval to the exclusion of other products or vendors that also may be suitable.

${ }^{1}$ Department of Horticulture, Michigan State University, East Lansing, MI 48824. ${ }^{2}$ Department of Plant Pathology and Physiology, Clemson University, Clemson, SC 29634.
2000 varieties of ornamental plants, extensive training of personnel is required to implement an IPM approach and it is very time intensive in practice.

This project investigated the impact of IPM on fungicide amounts transported in runoff water from application site at a container nursery. Specific goals of the study were 1) comparison of fungicide amounts in runoff water from IPM vs. preventative applications; 2) quantification of movement of three fungicides in runoff water from applications at a container plant nursery; and 3) documentation of marketable container plants under IPM and preventative pesticide application management strategies.

\section{Fungicides in study}

Thiophanate-Methyl. Thiophanate-methyl (dimethyl 4,4'(O-phenylene)bis(3-thioallophanate) is a systemic fungicide that is widely used in the container nursery industry because of its range of activity against pathogenic fungi including Fusarium root diseases, Rhizoctonia stem diseases, Alternaria leaf spots, Cyclindrocladium cutting rot, and powdery mildews (Chase, 1992; Dumroese et al., 1990; Mercer, 1971). Thiophanate-methyl is a benzimidazole compound closely related to benomyl. Both benomyl and thiophanate-methyl are unstable in nature and are quickly hydrolyzed to carbendazim (MBC), which is thought to be the primary toxic agent to fungi. Conversion in soil is faster at a neutral versus an acidic $\mathrm{pH}$ and microorganisms may be partly responsible for conversion (Fleeker et al., 1974). However, thiophanate-methyl is stable in ambient aqueous solutions below $\mathrm{pH} 9$ through $50 \mathrm{~d}$, but degradation rate to $\mathrm{MBC}$ increases as the $\mathrm{pH}$ is raised from 9 to 13 (Courtney, 1977). Degradation is also promoted at higher than ambient temperatures.

Thiophanate-methyl is relatively insoluble in water but readily dispersible in water. It does not strongly adsorb to soil particles and is not volatile (Table 1). Reported in vivo half life $\left(\mathrm{DT}_{50}\right)$ of thiophanate-methyl varies from 10 to $15 \mathrm{~d}$ on apple and grape leaves (Soeda et al., 1972), though Sclerotinia sclerotiorum control in muskmelon persisted through 10 weeks from a drench application (Netzer and Dishon, 1973). Rainfall following foliar 
Table 1. Chemical properties of fungicides in study (source: Wauchope et al., 1992).

\begin{tabular}{lccrc}
\hline \hline & $\begin{array}{c}\text { Water } \\
\text { solubility } \\
\left(\mu \mathrm{g} \cdot \mathrm{mL}^{-1}\right)\end{array}$ & $\begin{array}{c}\text { Vapor } \\
\text { pressure } \\
(\mathrm{mm} \mathrm{Hg})\end{array}$ & $\begin{array}{c}\mathrm{K}_{\mathrm{H}} \\
\left(\mathrm{Pa} \cdot \mathrm{m}^{3} \cdot \mathrm{mol}^{-1}\right)\end{array}$ & $\begin{array}{c}\text { Field } \\
\mathrm{DT}_{50} \\
\left(\mathrm{~mL} \cdot \mathrm{g}^{-1}\right)\end{array}$ \\
\hline Chemical & 0.6 & $10^{-3}$ & $2.2 \times 10^{-2}$ & 1380 \\
Chlorothalonil & 8400 & $5.6 \times 10^{-6}$ & $2.5 \times 10^{-5}$ & 30 \\
Metalaxyl & $3.5 \mathrm{a}$ & $<10^{-7}$ & $<9.3 \times 10^{-4}$ & 70 \\
Thiophanate-methyl & & & 1830 \\
\hline
\end{tabular}

application caused a rapid decline in MBC concentrations in soybean leaves suggesting dislodging of foliar residues of thiophanate-methyl (Lyons and Lyda, 1987). Thiophanate-methyl was detected in runoff water from a container nursery (Briggs et al., 1998a). The fungicide is toxic to fish at levels above its water solubility. It is not very toxic to birds and carries an EPA toxicity class rating of IV indicating mild toxicity (Kidd and James, 1991).

Chlorothalonil. Chlorothalonil (tetrachloroisophthalonitrile) is a broad spectrum, organochlorine, nonsystemic, foliar fungicide. It is used on ornamentals for prophylactic control of leaf spots and foliar blights (e.g. Anthracnose sp., Cercospora sp., Fusarium sp. and Rhizoctonia sp.), Phytophthora dieback diseases and powdery mildews (Bowen and Young, 1995). Toxicity to fungal cells results from binding of chlorothalonil with sulfhydryl groups of cellular proteins leading to irreversible enzyme deactivation (Long and Seigle, 1975). Between 1990 and 1996, $2 \%$ of the total chlorothalonil (a.i.) applied in the United States was on container grown crops (U.S. EPA, 1999).

Chlorothalonil is relatively insoluble in water, is not highly volatile and adsorbs only slightly to soils (Table 1). Persistence was measured as $30 \mathrm{~d}$ in field soils, but was 11 to $13 \mathrm{~d}$ in flower bulb soils (low-humic, sandy soils) at $15{ }^{\circ} \mathrm{C}$ (van der Pas et al., 1999). In a quartz sand soil after 14 d, $43 \%$ of applied chlorothalonil was in solution, $26 \%$ was in a labile sorbed state and $31 \%$ was a bound residue (Gamble et al., 2000). Contrary to behavior of most pesticides, repeated applications of chlorothalonil suppress degradation due to toxicity of a persistent and highly mobile chlorothalonil metabolite (hydroxy-chlorothalonil) to soil biomass (Motonaga et al., 1998).

Chlorothalonil is classified as EPA toxicity class II (moderately toxic) because of potential eye irritation from certain formulations. It is minimally toxic to birds, but highly toxic to fish at low concentrations. Reported $\mathrm{LC}_{50}(96 \mathrm{~h})$ is $0.25 \mu \mathrm{g} \cdot \mathrm{mL}^{-1}$ for rainbow trout, $0.3 \mu \mathrm{g} \cdot \mathrm{mL}^{-1}$ for bluegill fish and $0.42 \mu \mathrm{g} \cdot \mathrm{mL}^{-1}$ for channel catfish (Kidd and James, 1991).

Metalaxyl. Metalaxyl ( $N$-(2,6-dimethylphenyl)- $N$ methoxyacetyl)alanine methyl ester) is a systemic fungicide that is widely used in agriculture and horticultural crops for control of root and stem diseases and damping off of seedlings. This fungicide is especially effective against plant pathogens in the order Peronosporales including Phytophthora sp. and Pythium sp. (Sukul and Spiteller, 2000). In ornamental production, metalaxyl is also used to control rots of roots and crowns including Rhizoctonia stem rot (Benson, 1992; Ferrin, 1992). Application may be by spraying, by drench or in a granular form. When used in conjunction with other fungicides such as copper compounds, dithiocarbamates and phthalimides, the control spectrum is broadened, and development of resistant fungal strains is prevented or delayed (Fontem and Aighewi, 1993).

Metalaxyl is very soluble in water, moderately volatile, and weakly adsorbed to soils (Table 1). However, preferential adsorption on soil mineral surfaces was found, and $\mathrm{K}_{\mathrm{oc}}$ may not best describe adsorption in mineral soils (Sukop and Cogger, 1992). Metalaxyl is stable over a wide range of $\mathrm{pH}$, temperature and light conditions. Persistence in water was measured at $84 \%$ at 12 weeks (Sharom and Edgington, 1982), and reported soil DT D $_{50}$ is 3 to 10 weeks (Di et al., 1998). Metalaxyl may be substantially leached in mineral soils dependent upon organic matter content of the soil and rainfall intensity (Sharom and Edgington, 1982).

Metalaxyl is an acylanide chemical that is a mixture (50:50) of $\mathrm{R}$ - and S-enantiomeric forms. The R-enantiomeric form (mefenoxam) is more biologically active than the S-form and is currently being marketed at recommended rates that are one half those for metalaxyl. This fungicide carries an EPA toxicity rating of III indicating moderate toxic effects, but is only minimally toxic to birds and fish (Kidd and James, 1991).

\section{Materials and Methods}

During Summer 1998, a large-scale field study was initiated at Gilbert's Nursery, near Chesnee, S.C. Eight contiguous production beds surfaced with landscape fabric over plastic were randomly divided into two treatments: 1) preventative pesticide applications in which fungicides were applied on a monthly basis to the entire bed; and, 2) IPM based pesticide applications in which fungicides were applied only to affected plant species when signs of fungal pathogens or damage were observed. Each bed housed 25 taxa of container plants (155 of each taxa per bed) in 11-L pots (see Table 2 for plant list). Plant taxa were arranged identically within the replicated beds, and there were four replications of each treatment.

Fungicide applications in IPM beds were based on weekly scouting results. Five plant taxa, selected for their known propensity for pest problems, were scouted intensively. Plants were 'Tuscarora' crape myrtle (Lagerstroemia indica L.), 'Coral Bells' azalea (Rhododendron xobtusum Planch.), 'Blaauw's Pink' azalea [Rhododendron xobtusum Planch.], 'Dwarf Burford' holly (Ilex cornuta Lindl. \& Paxt.) and 'Grey Owl' juniper (Juniperus virginiana L.). Five scouting areas were marked within each of the five plant taxa. Each scouting site consisted of 10 container plants, and weekly, a different plant would be scouted for pathogen signs and symptoms. The remaining plant taxa were also scouted on a weekly basis using a walk-through observational technique to detect pests. Container plants exhibiting symptoms of pathogen infestation were submitted to the Plant Problem Clinic at Clemson University for diagnosis.

Three applications of fungicides were applied to beds during the summer of 1998. On 7 July 1998, Cleary's 3336 (50\% thiophanate-methyl) (Cleary's Corporation, Dayton, N.J.) and Daconil 2787 (82.5\% chlorothalonil) (Zeneca Professional Products, Wilmington, Del.) were spray applied to the preventative treatment only. Application rates were $0.7 \mathrm{~kg} \cdot \mathrm{ha}^{-1}$ a.i. thiophanatemethyl, and $0.8 \mathrm{~kg} \cdot \mathrm{ha}^{-1}$ a.i. chlorothalonil. Fungicides were tank mixed and applied with an air blast sprayer delivering $193 \mathrm{~L} \cdot \mathrm{ha}^{-1}$. Pulse irrigation consisting of three 30-min cycles (hereafter 
Table 2. Plant list of ornamental species in research beds.

\begin{tabular}{|c|c|}
\hline Botanical name & Common name \\
\hline Abelia ×`Edward Goucher’ [A. ×grandiflora (André) Rehd. $\times$ A. schumannii (Grabn.) Rehd.] & Edward Goucher abelia \\
\hline Abelia $\times$ grandiflora (André) Rehd. 'Richardii' & Glossy abelia \\
\hline Agarista populifolia (Lam.) Judd & Agarista \\
\hline Berberis thunbergii var. atropurpurea DC. 'Rose Glow' & Red barberry \\
\hline Chamaecyparis obtusa (Sieb. \& Zucc.) Endl. 'Gold Mop' & Gold mop hinoki falsecypress \\
\hline Chamaecyparis obtusa (Sieb. \& Zucc.) Endl. 'Gracilis' & Gracilis hinoki falsecypress \\
\hline Ilex $\times$ 'Emily Bruner' (I. cornuta Lindl. \& Paxt. 'Burfordii' $\times$ I. latifolia Thunb.) & Emily Bruner holly \\
\hline Ilex cornuta Lindl. \& Paxt. 'Dwarf Burford' & Dwarf burford holly \\
\hline Ilex crenata Thunb. 'Helleri' & Helleri Japanese holly \\
\hline Ilex verticillata (L.) A. Gray 'Jim Dandy' & Jim Dandy winterberry \\
\hline Ilex verticillata (L.) A. Gray 'Red Sprite' & Red sprite winterberry \\
\hline Ilex verticillata $($ L.) A. Gray 'Winter Red' & Winter red winterberry \\
\hline Lonicera pileata Oliv. 'Royal Carpet' & Royal carpet privet honeysuckle \\
\hline Loropetulum chinense var. rubrum (R. Br.) Oliv. & Loropetulum \\
\hline Raphiolepsis $\times$ delacourii André & Dwarf Indian hawthorne \\
\hline Rhododendron ×obtusum Planch. 'Blaauw's Pink' (Blaauw) & Blaauw's pink azalea \\
\hline Rhododendron $\times$ obtusum Planch. 'Coral Bells' & Coral bells azalea \\
\hline Thuja occidentalis L. 'Emerald' ('Smaragd’) & Emerald arborvitae \\
\hline Thuja occidentalis L. 'Hetz Midget' & Hetz midget arborvitae \\
\hline
\end{tabular}

designated as pulse A, B, or C), with a 90-min rest between cycles, was applied on the day after application (DAA). Irrigation totaled $1.8 \mathrm{~cm}(0.6 \mathrm{~cm}$ per cycle). Runoff samples $(400 \mathrm{~mL})$ were collected in silanized glass jars from weirs at 15-min intervals for all pulse cycles beginning when runoff through the weirs reached a height of $25 \mathrm{~mm}$. Three runoff samples (designated as 1, 2, and 3 ) were taken from each of the three pulse cycles for a total of nine runoff samples. Additionally, runoff flow height was measured at the weir at 15-min intervals to allow determination of total runoff volume. Runoff amounts were 1300, 2600, and 3100 L from pulse cycles A, B and C, respectively. Total runoff volume was $24 \%$ of irrigation amount resulting in an irrigation efficiency of $76 \%$. This is similar to other field studies at a container nursery in which pulsed overhead irrigation resulted in an irrigation efficiency of $60 \%$ to $80 \%$ (Briggs et al., 1998b; 2002).

On 4 Aug. 1998, thiophanate-methyl and chlorothalonil were applied as described above to the preventative treatment. In the IPM treatment, fungicides were applied to 'Nikko' blue bigleaf hydrangea, as it was the only plant species exhibiting symptoms of fungal pathogen infestation. Fungicide rates for the IPM treatment were as for the preventative treatment but application was made in $8 \mathrm{~L}$ of solution per replication, using a pump-up 11L sprayer. Pulse irrigation was applied at rates of $0.7,0.9$ and 0.7 $\mathrm{cm}$ per pulse cycle and runoff samples were collected as previously described. Runoff amounts were 1700, 3500 and $4200 \mathrm{~L}$ per bed for pulse cycles A, B and C, respectively. Total runoff amount was $24 \%$ of irrigation amount, as in the July study.

On 2 Sept. 1998, Subdue GR (1\% metalaxyl) (Novartis Crop Protection, Greensboro, N.C.) was applied to all plant species in the preventative treatment and to four plant species in the IPM treatment that were manifesting symptoms of Phytophthora diseases. Application rate was $2.0 \mathrm{~kg} \cdot \mathrm{ha}^{-1}$ a.i. The granular product was broadcast applied with hand held crank type spread- ers. Pulse irrigation was applied in two 30-min cycles with a 90 min rest between cycles $(1.2 \mathrm{~cm}$ total $)$. Runoff samples were taken at 15-min intervals of runoff flow from the first pulse cycle (samples A-1, A-2, and A-3) and one runoff sample was taken from the second cycle $(B)$ at $\approx 15$ min of runoff flow. Runoff volumes averaged 2150 and $3430 \mathrm{~L}$ from pulse $\mathrm{A}$ and B, respectively, and runoff amount was $29 \%$ of irrigation amount.

EXTRACTION AND ANALYSIS. Runoff samples were stored at $4{ }^{\circ} \mathrm{C}$ until extraction. The $\mathrm{pH}$ of ambient samples was adjusted to 2.2 to 2.3 using $6 \mathrm{~N}$ HCL to fully protonate hydroxyl side groups. Two hundred $\mathrm{mL}$ of runoff water was filtered through Whatman \# 5 filter paper using a Buchner funnel. Fungicides were vacuum extracted from water samples onto $\mathrm{C}_{18}$ solid phase extraction cartridges that had been activated with $10 \mathrm{~mL}$ acetone and rinsed with $10 \mathrm{~mL}$ water. Fungicides were eluted with $2 \mathrm{~mL}$ acetone and the solution was filtered through a $0.2-\mu \mathrm{m}$ filter into amber autosampler vials. Sample analysis was by high pressure liquid chromatography (HPLC). HPLC run conditions for analysis of thiophanate-methyl and chlorothalonil were 40 acetonitrile : 60 water with $2 \%$ acetonitrile gradient flow to $80: 20$ over $30 \mathrm{~min}$. Acetonitrile (100\%) was then pumped for $5 \mathrm{~min}$ followed by 5 min of the starting solvent. The column was a Rexchrom $\mathrm{C}_{18}(3$ $\mu \mathrm{m}, 10 \mathrm{~cm}$ by $4.6 \mathrm{~mm}$ I.D.) (Regis Technologies, Morton Grove, Ill.). Flow rate was $0.5 \mathrm{~mL} \cdot \mathrm{min}^{-1}$ and injection volume was $50 \mu \mathrm{L}$. The diode array detector was set at $206 \mathrm{~nm}$. HPLC run conditions for metalaxyl analysis were 40:60 acetonitrile:water with $2 \%$ acetonitrile gradient flow to $100 \%$ acetonitrile over $20 \mathrm{~min} ; 100 \%$ acetonitrile 20 to $25 \mathrm{~min}$; 40:60 starting solvent 25 to $30 \mathrm{~min}$. Metalaxyl samples were diluted 1:9 with acetone before HPLC analysis, as concentrations were very high. Percent recoveries were $117 \%, 124 \%$, and $85 \%$ for thiophanate-methyl, chlorothalinol, and metalaxyl, respectively, and limits of detection were $10 \mathrm{ppb}$. 
Container Plant salability. IPM based pesticide applications will only be adopted by the container nursery industry if plant health is not compromised. To document the impact of the two management strategies on plant health, the number of culls (unsalable containers) of individual plant species in treatments was counted. Containers were designated as culls if defoliation had occurred or if pathogen presence was observable. Nursery personnel performed this evaluation in November 1998, prior to containers being moved to overwintering houses.

STATISTICAL analYSIS. Treatment means of runoff samples for sampling periods and dates were separated using ANOVA combined with the Student's $t$ test.

\section{Scouting results}

\section{Results}

Disease symptoms were first manifested on 'Nikko' blue bigleaf hydrangea and were determined to be caused by a Colletotrichum sp. Phytophthora sp. was detected in the substrate of coniferous container plants \{ 'Gold Mop' Hinoki false cypress [Chamaecyparis obtusa (Sieb. \& Zucc.) Endl.], 'Gracilis' hinoki falsecypress [Chamaecyparis obtusa (Sieb. \& Zucc.) Endl.]\}, and 'Coral Bells' azalea in July and August. Pythium sp. was also isolated from container substrate of 'Emerald' ('Smaragd') arborvitae (Thuja occidentalis L.). Irrigation volume was reduced from three to two pulse cycles in August to prevent proliferation of water spread fungal inoculum in runoff water.

\section{Fungicide movement in runoff water}

JulY APPLICATION. Thiophanate-methyl was detected in all runoff samples in the preventative treatment on the DAA. It was not detected from IPM treatment beds indicating that minimal to no contamination of nontarget treatment beds had occurred during pesticide application. The greatest concentrations were found in the first pulse irrigation cycle (A), and concentrations were lowest from the third pulse cycle (C) (Table 3). The highest concentration detected was $1.36 \mu \mathrm{g} \cdot \mathrm{mL}^{-1}$ from the third runoff sample in pulse A, below maximum water solubility of thiophanatemethyl (Table 1).

Concentrations were multiplied by runoff volume for specific sampling periods to determine amounts transported in runoff water. Greater amounts of thiophanate-methyl were transported in runoff water during pulse irrigation cycles $\mathrm{A}$ and $\mathrm{B}$ than $\mathrm{C}$. Amounts of the fungicide detected were 3.6, 4.1, and $0.3 \mathrm{~g}$ from pulse cycles A, B and C, respectively [LSD $(P \leq 0.05)=1.4$ ] (Table 3). Total amount detected in runoff water on the DAA was $7 \%$ of the applied amount.

Chlorothalonil was detected in all runoff samples on the DAA. Greatest concentration found was $0.95 \mu \mathrm{g} \cdot \mathrm{mL}^{-1}$ in the first runoff sample which is slightly above reported maximum solubility indicating some transport of dispersed chemical not in solution (Table 3). Concentrations declined throughout the sampling period and were lowest in the last two runoff samples from pulse cycle C. While greatest chlorothalonil concentrations found were similar to results with thiophanate-methyl, lowest levels detected were $10 \times$ amounts of thiophanate-methyl. Greatest amounts of chlorothalonil were found in runoff from the second pulse cycle (B) [LSD $(P \leq 0.05)$ of pulse total amounts $=1.5]$. As a percent of applied, $4 \%$ of chlorothalonil was detected in runoff water on the DAA.

August application. Thiophanate-methyl was detected at much greater concentrations from the preventative treatment than the IPM treatment, as expected (Table 4). In both treatments, thiophanate-methyl was only found in runoff from pulse cycles A and B. Levels were below limits of detection for pulse cycle C. Highest concentrations were noted in the first runoff samples, and declined throughout the sampling period for both treatments. Concentrations from the preventative treatment were similar to levels noted in July.

Chlorothalonil was also detected at higher concentrations from the preventative treatment than the IPM treatment (Table 4), and was found in all runoff samples from both treatments. Greatest concentrations were noted in the first runoff sample from the preventative treatment $\left(0.80 \mu \mathrm{g} \cdot \mathrm{mL}^{-1}\right)$ and the second sample from the IPM treatment $\left(0.27 \mu \mathrm{g} \cdot \mathrm{mL}^{-1}\right)$, with levels declining in subsequent pulse cycles. Chlorothalonil concentrations were similar to results obtained from the July application.

Total amounts of thiophanate-methyl leaving application site in runoff water were $2 \%$ of applied amount from the preventative treatment and $37 \%$ from the IPM treatment (Table 5). Differences in percent of applied amounts may be the result of application method and/or the location of the treated containers in the IPM treatment. Wind transported spray solution from the mist appli-

Table 3. Concentrations $\left(\mu \mathrm{g} \cdot \mathrm{mL}^{-1}\right)$ and amounts $(\mathrm{g})$ of fungicides detected in runoff water from preventative treatment beds in July 1998 for samples $(1,2$, and 3$)$ in pulse cycles $\mathrm{A}, \mathrm{B}$, and $\mathrm{C}$. Means are of $\mathrm{n}=4$ replications.

\begin{tabular}{|c|c|c|c|c|}
\hline \multirow{2}{*}{$\begin{array}{l}\text { Runoff } \\
\text { (pulse sample) }\end{array}$} & \multicolumn{2}{|c|}{ Thiophanate-methyl } & \multicolumn{2}{|c|}{ Chlorothalonil } \\
\hline & $\left(\mu \mathrm{g} \cdot \mathrm{mL}^{-1}\right)$ & (g) & $\left(\mu \mathrm{g} \cdot \mathrm{mL}^{-1}\right)$ & (g) \\
\hline$\overline{\mathrm{A}-1}$ & 1.01 & 0.4 & 0.95 & 0.4 \\
\hline A-3 & 1.36 & $\underline{1.9}$ & 0.68 & $\underline{1.0}$ \\
\hline Subtotal & & 3.6 & & 2.3 \\
\hline B-1 & 1.06 & 0.7 & 0.83 & 0.5 \\
\hline Subtotal & & $\overline{4.1}$ & & $\overline{3.0}$ \\
\hline $\mathrm{C}-1$ & 0.24 & 0.1 & 0.51 & 0.2 \\
\hline $\mathrm{C}-2$ & 0.10 & 0.2 & 0.32 & 0.5 \\
\hline $\mathrm{C}-3$ & 0.03 & $\underline{0.1}$ & 0.34 & $\underline{0.7}$ \\
\hline Subtotal & & 0.3 & & 1.4 \\
\hline $\operatorname{LSD}(P \leq 0.05)$ & 0.49 & 0.7 & 0.46 & 0.7 \\
\hline
\end{tabular}


Table 4. Thiophanate-methyl and chlorothalonil concentrations $\left(\mu \mathrm{g} \cdot \mathrm{mL}^{-1}\right)$ in runoff from the preventative and IPM treatments for samples $(1,2$, and 3 ) in pulse cycles A, B, and C, from the August application. Means are of $n=4$ replications.

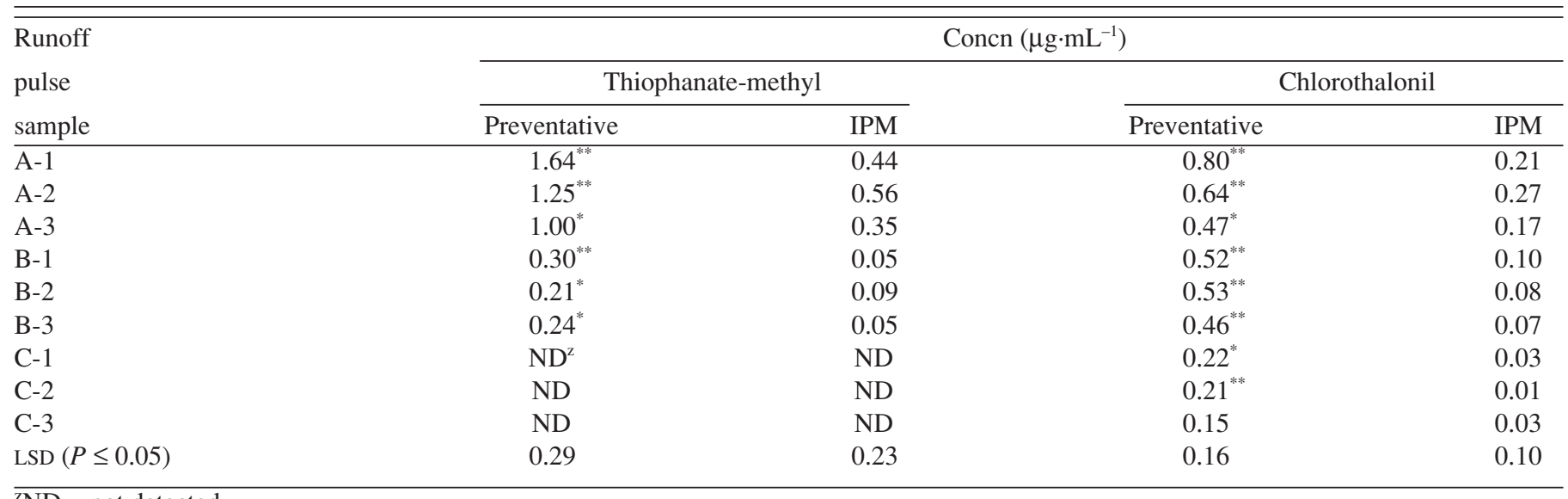

${ }^{\mathrm{z}} \mathrm{ND}=$ not detected.

${ }^{* * * *}$ Significant at $P \leq 0.05$ and 0.01 , respectively, in rows for a sample between treatments.

cation to the preventative treatment beds may have resulted in contamination of IPM beds, and/or hand spraying of the IPM treatment may have resulted in greater deposits of fungicide on foliage as compared to the air blast mist application. Additionally, the area to which fungicides were applied in the IPM treatment was near the bottom of the beds, close to the sampling site, possibly accounting for the differences in treatment amounts detected. Smaller amounts of thiophanate-methyl were detected in runoff than in July, possibly a result of increases in plant absorption due to increased foliage area resulting from plant growth.

Total amounts of chlorothalonil detected leaving application site in runoff water were $4 \%$ of applied amount from the preven- tative treatment and 12\% from the IPM treatment (Table 5). Differences in percent of applied amounts may be the result of application method and placement, as discussed previously.

SEPtember application. Metalaxyl was detected at higher concentrations from the preventative treatment than the IPM treatment in all runoff samples (Table 6). Highest level detected was $61 \mu \mathrm{g} \cdot \mathrm{mL}^{-1}$ for the preventative treatment and $30 \mu \mathrm{g} \cdot \mathrm{mL}^{-1}$ for the IPM treatment in the first runoff samples. Concentrations declined through the sampling period in both treatments. Amounts of metalaxyl detected in runoff water were also higher from the preventative treatment in all samples (Table 6). As a percent of applied amount, $25 \%$ was noted in runoff water in the preventative treatment and $30 \%$ was found from the IPM treatment.

Table 5. Thiophanate-methyl and chlorothalonil amounts ( $\mathrm{g}$ ) in runoff water for the preventative and IPM treatments for pulse cycles A, B, and C, from the August application. Means are of $n=4$ replications.

\begin{tabular}{|c|c|c|c|c|}
\hline \multirow{2}{*}{$\begin{array}{l}\text { Runoff } \\
\text { pulse }\end{array}$} & \multicolumn{4}{|c|}{ Amount (g) } \\
\hline & Preventative & IPM & Preventative & IPM \\
\hline B & $1.6^{*}$ & 0.5 & $3.5^{* *}$ & 0.5 \\
\hline $\mathrm{C}$ & $\mathrm{ND}^{\mathrm{z}}$ & ND & $1.4^{*}$ & 0.2 \\
\hline $\operatorname{LSD}(P=0.05)$ & 0.5 & 0.4 & 0.8 & 0.4 \\
\hline
\end{tabular}

${ }^{\mathrm{z}} \mathrm{ND}=$ not detected.

${ }^{* * * *}$ Significant at $P \leq 0.05$ and 0.01 , respectively, respectively, in rows for a sample between treatments.

Table 6. Metalaxyl concentrations $\left(\mu \mathrm{g} \cdot \mathrm{mL}^{-1}\right)$ and amounts $(\mathrm{g})$ detected in runoff water for the preventative and IPM treatments in samples 1,2 and 3 from pulse A and one sample from pulse B. Means are of $n=4$ replications.

\begin{tabular}{|c|c|c|c|c|}
\hline \multirow{2}{*}{$\begin{array}{l}\text { Runoff } \\
\text { sample }\end{array}$} & Preventative & IPM & Preventative & IPM \\
\hline & \multicolumn{2}{|c|}{$\left(\mu \mathrm{g} \cdot \mathrm{mL}^{-1}\right)$} & \multicolumn{2}{|c|}{$\mathrm{g}$} \\
\hline$\frac{1}{A-1}$ & $61.0^{*}$ & 30.1 & $6.4^{*}$ & 3.2 \\
\hline A-3 & $29.1^{* * *}$ & 3.1 & $14.8^{* * *}$ & 1.6 \\
\hline B & $16.6^{*}$ & 5.1 & $33.1^{*}$ & 10.3 \\
\hline $\operatorname{LSD}(P=0.05)$ & 19.8 & 18.4 & 16.1 & 7.1 \\
\hline
\end{tabular}

${ }^{* * * *}$ Significant at $P \leq 0.05$ and 0.01 , respectively, in rows for a sample between treatments. 
Table 7. Unsalable container plants (percent of total plants) in the preventative and IPM fungicide application treatments at the end of the study.

\begin{tabular}{lccc}
\hline \hline $\begin{array}{l}\text { Plant } \\
\text { species }\end{array}$ & Preventative & $\begin{array}{c}\text { IPM } \\
(\%)\end{array}$ & $(P=0.05)$ \\
\hline Coral bells azalea & 0.3 & 0.5 & 0.8 \\
Emerald arborvitae & 1.6 & 5.2 & 7.1 \\
Gold mop Hinoki falsecypress & 3.5 & 5.0 & 3.4 \\
'Nikko blue' bigleaf hydrangea & 0.5 & 2.6 & 2.8 \\
Total & 1.5 & 3.3 & $1.9 \mathrm{a}^{\mathrm{z}}$ \\
\hline
\end{tabular}

${ }_{\mathrm{LSD}}(P=0.10)=1.6$.

\section{Container plant health}

Culls were noted in only four of the plant taxa and total losses were $220 \%$ higher from the IPM treatment than in the preventative treatment. However, no significant differences were found between treatments either within a plant species or as a total for the study (Table 7).

\section{Discussion}

The five plant taxa selected for intensive scouting did not display anticipated fungal infestations of the magnitude projected resulting in a minimal use of fungicides in the IPM treatment during this study. Pathogens were detected on plant taxa that were visually scouted on a weekly basis and fungicides were applied to the IPM treatment in response. If different plant species had been selected for intensive scouting, fungicide use may have increased in the IPM treatment. However, production nurseries would follow procedures similar to those implemented in this study. Large container nurseries produce several thousand different varieties of plants and problem-prone plant taxa would be scouted most intensively.

Concentrations and amounts of thiophanate-methyl detected following the July and August applications are similar to previously published results (Briggs et al., 1998a, 1998b). In this study, the maximum thiophanate-methyl concentration detected was $1.6 \mu \mathrm{g} \cdot \mathrm{mL}^{-1}$ (August). In an earlier study investigating pesticide movement under continuous irrigation conditions, the maximum level detected was $5 \mu \mathrm{g} \cdot \mathrm{mL}^{-1}$ from an application that was $3 \times$ the rates used in this study (Briggs et al., 1998a). The maximum level detected in runoff generated by pulse irrigation following an application at rates used in this study was $0.67 \mu \mathrm{g} \cdot \mathrm{mL}^{-1}$ (Briggs et al., 1998b). However, runoff water was channeled through a grass waterway prior to sampling. Filtering and adsorption mechanisms of the grass waterway would account for the lower level detected.

In earlier studies, thiophanate-methyl amount recovered on the day of application in runoff generated by continuous irrigation was $2.1 \%$ of applied amount, and was $1.5 \%$ in runoff from pulse irrigation (Briggs et al., 1998a, 1998b). In this study, 7\% and $3.5 \%$ of applied were detected from the preventative application in July and August, respectively. Greater amounts found in this study are probably the result of the location at which runoff samples were taken. In this project, sampling sites were located at the base of production beds (edge of field) and in earlier studies, runoff sampling site was located 20 to $30 \mathrm{~m}$ downslope of production beds.

Thiophanate-methyl is not subject to volatilization or photodegradation after application. Moderate adsorption to organic matter is noted in field soils (Hornsby et al., 1995). Adsorption was presumed to be minimal in this study due to the use of artificial and inorganic production bases where the major- ity of the applied fungicide landed. However, Nerín et al. (1996) found that many pesticides were completely absorbed on lowdensity polyethylene films after $15 \mathrm{~d}$. Absorption by the production base and the plant material was not quantified in the current study, but may be an important fate for applied thiophanatemethyl at a container nursery.

Chlorothalonil is practically insoluble in water, has a minimal tendency for volatilization, and is only moderately adsorbed to organic components in soil. In this study, concentrations slightly above the reported maximum water solubility of chlorothalonil were found in runoff water, indicating some transport of undissolved chemical (bulk flow). Because of the widespread use of this fungicide and its toxicity to aquatic organisms at low levels, reports exist on leaching potential in soils. Risk of groundwater contamination is reported to be minimal (Reduker et al., 1988; van der Pas et al., 1999; Winnett et al., 1990). Greatest concentration found in leachates from soil columns was $0.3 \mu \mathrm{g} \cdot \mathrm{mL}^{-1}$ (Reduker et al., 1988), and much lower levels were detected in a field study (Winnett et al., 1990).

No documentation could be located describing chlorothalonil movement in runoff water, though the fungicide was detected in surface water at a maximum concentration of $0.68 \mu \mathrm{g} \cdot \mathrm{L}^{-1}$ (U.S. EPA, 1999). Results of the current study indicate that substantial levels of chlorothalonil (4\% of applied amount) move from application site in runoff water at a container nursery. Implementation of IPM for determining pesticide application timing is effective in reducing amounts of chlorothalonil transported in runoff water.

Metalaxyl is a highly water-soluble compound with a very low affinity for soils and organic matter. Metalaxyl was detected at $7 \%$ of applied amount in leachates from soil columns covered with turfgrass (Starrett et al., 1996), and 36\% of applied metalaxyl was detected in leachates from a sand growth substrate (Petrovic et al., 1996). Amounts detected in this study indicate that the potential for metalaxyl to leave application site in runoff water is great. Though concentrations detected in edge of field runoff water were below levels toxic to fish, broadcast applications should not be made at container nurseries. Metalaxyl is stable in aqueous solutions for long periods (Sharom and Edgington, 1982) and repeat applications could result in a buildup to toxic concentrations.

Though threatening pathogens were identified during the study, prescriptive fungicide applications (IPM) to affected plant species did not result in a significant increase in plant losses as compared to preventative pesticide applications. Noted should be that in this study production beds housed a variety of plant material as plant diversity is a basic tenet of IPM. However, this may be atypical of production practices at a large container nursery and if large populations of individual plant taxa are present, plant losses may be economically important.

In this study, plant quality and fungicide amounts in runoff 
water were evaluated under preventative and IPM based pesticide applications through one growing season at a container plant nursery. Implementation of IPM strategies effectively reduced amounts of fungicides transported in runoff water, without compromising container plant health and marketability. Total amounts of thiophanate-methyl, chlorothalonil and metalaxyl detected in runoff water were $12.5,12.8$, and $83.4 \mathrm{~g}$ for the preventative treatment and 1.5, 1.2, and $20.6 \mathrm{~g}$ from the IPM treatment, respectively. Greatest concentrations detected for all fungicides were below $\mathrm{LD}_{50}$ toxicity levels to aquatic organisms, and risks to aquatic ecosystems associated with the use of these pesticides appear to be minimal. However, repeated applications of metalaxyl and chlorothalonil may result in a buildup of contaminants in surface water based on reported half-life values. Implementation of IPM pesticide application strategies would result in smaller amounts of pesticides transported in runoff water.

\section{Literature Cited}

Benson, D.M. 1992. Fungicides as foliar sprays or rooting cube soaks in propagation of poinsettia. HortScience 27:1006-1008.

Bowen. K.L. and B. Young. 1995. Management of blackspot of rose in the landscape in Alabama. Plant Dis. 79:250-253.

Briggs, J.A., M.B. Riley, and T. Whitwell. 1998a. Quantification and remediation of pesticides in runoff water from containerized plant production. J. Environ. Quality 27:814-820.

Briggs, J., T. Whitwell, M.B. Riley, and T. Lee. 1998b. Cyclic irrigation and pulsed waterways combine to reduce isoxaben losses from container plant nurseries. J. Environ. Hort. 16:235-238.

Briggs, J.A., T. Whitwell, R.T. Fernandez, and M.B. Riley. 2002. Formulation effects on isoxaben and trifluralin in runoff water from container plant nurseries. Weed Sci. 50:536-541

Cardina, J., T.M. Webster, C.P. Herms, and E.E. Regnier. 1999. Development of weed IPM: Levels of integration for weed management. J. Crop Prot. 2:239-267.

Chase, A.R. 1992. Efficacy of thiophanate-methyl fungicides for diseases of Florida ornamentals. Proc. Fla. State Hort. Soc. 105:182-186.

Cook, R.J. 1994. The place for IPM in the next decade, p. 4-16. In: Proc. 2nd Natl. Integrated Pest Management Symp. Workshop.

Courtney, G.F. 1977. Stability of thiophanate-methyl in aqueous solutions. Pesticide Sci. 8:211-213.

Di, H.J., L.A.G. Aylmore, and R.S. Kookana. 1998. Degradation rates of eight pesticides in surface and subsurface soils under laboratory and field conditions. Soil Sci. 163:404-411.

Dumroese, R.K., R.L. James, and D.L. Wenny. 1990. Trial of a granular etridiazole and thiophanate-methyl mixture to control Fusarium root disease of container-grown Douglas-fir seedlings. New Forests 4:231236.

Ferrin, D.M. 1992. Population dynamics of Phytophthora parasitica, the cause of root and crown rot of Catharanthus roseus, in relation to fungicide use. Plant Dis. 76:60-63.

Fleeker, J.R., H.M. Lacy, I.R. Schultz, and E.C. Houkom. 1974. Persistence and metabolism of thiophanate-methyl in soil. J. Agr. Food Chem. 22:592-595.

Fontem, D.A. and B. Aighewi. 1993. Effect of fungicides on late blight control and yield loss of potato in the western highlands of Cameroon. Intl. J. Pest Mgt. 32:152-155.

Gamble, D.S., A.G. Bruccoleri, E. Lindsay, C.H. Langford, and G.A. Leys. 2000. Chlorothalonil in a quartz sand soil: speciation and kinetics. Environ. Sci. Technol. 34:120-124.

Holtzer, T.O., R.L. Anderson, M.P. McMullen, and F.B. Peairs. 1996. Integrated pest management of insects, plant pathogens, and weeds in dryland cropping systems of the great plains. J. Prod. Agr. 9:200-208.

Hornsby, A.G., R.D. Wauchope, and A.E. Herner. 1995. Pesticide properties in the environment. Springer, New York.

Kidd, H. and D.R. James. 1991. The agrochemical handbook. 3rd ed. Royal Soc. Chem. Info. Serv., Cambridge, U.K.

Long, J.W. and M.R. Seigle. 1975. Mechanism of action and fate of the fungicide chlorothalonil (2,4,5,6-tetrachloroisophtalonitrile) in biological systems. II. Chem. Biol. Interactions 10:383-394.

Lyons, P.C. and S.D. Lyda. 1987. Persistence of carbendazim in fieldgrown soybeans following application of thiophanate-methyl fungicide. Pesticide Sci. 19:221-228.

Mercer, R.T. 1971. Some studies on the systemic activity of the thiophanate fungicides in plants. Pesticide Sci. 2:214-218.

Motonaga, K., K. Takagi, and S. Matumoto. 1998. Suppression of chlorothalonil degradation in soil after repeated application. Environ. Toxicol. Chem. 17:1469-1472.

Nerín, C., A.R. Tornés, C. Domeño, and J. Cacho. 1996. Absorption of pesticides on plastic films used as agricultural soil covers. J. Agr. Food Chem. 44:4009-4014.

Netzer, D. and I. Dishon. 1973. Persistence of benomyl and thiophanatemethyl compounds in soil and various plants following soil application. Phytoparasitica 1: 33-37.

Petrovic, A.M., W.C. Barrett, I. Larsson-Kovach, C.M. Reid, and D.J. Lisk. 1996. The influence of a peat amendment and turf density on downward migration of metalaxyl fungicide in creeping bentgrass sand lysimeters. Chemosphere 33:2335-2340.

Reduker, S., C.G. Uchrin, and G. Winnett. 1988. Characteristics of the sorption of chlorothalonil and azinphos-methyl to a soil from a commercial cranberry bog. Bul. Environ. Contam. Toxicol. 41:633-641.

Sharom, M.S. and L.V. Edgington. 1982. The adsorption, mobility and persistence of metalaxyl in soil and aqueous solutions. Can. J. Plant Pathol. 4:334-340.

Soeda, Y., S. Kosaka, and T. Noguchi. 1972. The fate of thiophanatemethyl fungicide and its metabolites on plant leaves and glass plates. Agr. Biol. Chem. 36:931-936.

Starrett, S.K., N.E. Christians, and T.A. Austin. 1996. Movement of pesticides under two irrigation regimes applied to turfgrass. J. Environ. Qual. 25:566-571.

Sukop, M. and C.G. Cogger. 1992. Adsorption of carbofuran, metalaxyl, and simazine: $\mathrm{K}_{\mathrm{oc}}$ evaluation and relation to soil transport. J. Environ. Sci. Health B. 27:565-590.

Sukul, P. and M. Spiteller. 2000. Metalaxyl: persistence, degradation, metabolism, and analytical methods. Rev. Environ. Contam. Toxicol. 164:1-26.

U.S. Environmental Protection Agency. 1999. Chlorothalonil reregistration eligibility decision (RED). Office of Prevention, Pesticides and Toxic Substances, Washington, D.C. EPA 738-R-99-004.

van der Pas, L.J.T., A.M. Matser, J.J.T.I. Boesten, and M. Leistra. 1999. Behavior of metamitron and hydroxy-chlorothalonil in low-humic sandy soils. Pesticide Sci. 55:923-934.

Wauchope, R.D., T.M. Buttler, A.G. Hornsby,P.W.M. Augustijn Beckers, and J.P. Burt. 1992. The SCS/ARS/CES pesticide properties database for environmental decision making. Rev. Environ. Contam. Toxicol. 123:1-164.

Winnett, G., P. Marucci, S. Reduker, and C.G. Uchrin. 1990. The fate of chlorothalonil in ground water in commercial cranberry culture in the New Jersey pine barrens. J. Environ. Sci. Health A 25:587-595. 